\title{
Article \\ Rehabilitation in Intermittent Water Distribution Networks for Optimal Operation
}

\author{
Rui Gabriel Souza ${ }^{1,2}\left(\mathbb{D}\right.$, Gustavo Meirelles ${ }^{2}$, Bruno Brentan ${ }^{2}$ and Joaquín Izquierdo ${ }^{3, *}$ (D) \\ 1 Civil Engineering Department, Polytechnical Institute of PUC Minas, Belo Horizonte 30535-901, Brazil; \\ rui.g182@gmail.com \\ 2 Hydraulic Engineering and Water Resources Department, School of Engineering, Federal University of Minas \\ Gerais, Belo Horizonte 31270-901, Brazil; gustavo.meirelles@ehr.ufmg.br (G.M.); brentan@ehr.ufmg.br (B.B.) \\ 3 Fluing-Institute for Multidisciplinary Mathematics, Universitat Politècnica de València, Camino de Vera $\mathrm{s} / \mathrm{n}$, \\ 46022 Valencia, Spain \\ * Correspondence: jizquier@upv.es
}

check for updates

Citation: Souza, R.G.; Meirelles, G.; Brentan, B.; Izquierdo, J.

Rehabilitation in Intermittent Water Distribution Networks for Optimal Operation. Water 2022, 14, 88

https://doi.org/10.3390/

w14010088

Academic Editor: Pankaj Kumar

Received: 25 November 2021

Accepted: 28 December 2021

Published: 4 January 2022

Publisher's Note: MDPI stays neutral with regard to jurisdictional claims in published maps and institutional affiliations.

Copyright: (C) 2022 by the authors. Licensee MDPI, Basel, Switzerland. This article is an open access article distributed under the terms and conditions of the Creative Commons Attribution (CC BY) license (https:// creativecommons.org/licenses/by/ $4.0 /)$.

\begin{abstract}
Equitable distribution of water is a growing source of worry, and concerns water systems managers as water-stressed areas steadily increase and situations of water scarcity are becoming more frequent. The problem goes beyond just the water sector and globally affects many countries' economies since water resources have multiple uses (i.e., power generation, irrigation, etc.). One of the various strategies to overcome periods of extreme events (e.g., water scarcity) is the adoption of intermittent operation. Intermittent operation can minimize water losses, and manages to supply the same water demand (in terms of volume) during a reduced period of time. However, despite minimizing water losses, the energy consumption necessary to cope with the increased flows and head loss, due to the reduced number of operating hours, increases. This paper explores a strategy based on rehabilitation of the system's main pipes. It also considers optimal selection and scheduling of pumps aiming at improving the system's hydraulic parameters (e.g., velocity and head losses) and at reducing the operating costs. Both selection and scheduling of pumps and resizing of main pipes are optimized using Particle Swarm Optimization. The obtained results show that this strategy can significantly reduce the energy consumed and can be economically feasible.
\end{abstract}

Keywords: rehabilitation; intermittent operation; optimization; water scarcity; water distribution

\section{Introduction}

Water is an essential resource for human survival and for the economic, social and health development of societies. However, in many regions of the planet, matching the required demand has become an arduous task due to water scarcity. It is estimated that $58 \%$ of the population were living in water-stressed areas in the early 2000s [1,2], and this number could reach 5 billion people by 2050 [2,3].

One of the aggravated problems is the intermittence of water supply, affecting $70 \%$ of consumers in Asia [4], 50\% in Africa, and 33\% in Latin America [5,6], totaling approximately one-third of the world population [7,8]. Brazil also has problems with water scarcity. As an example, in the years 2014 to 2016, the southeastern region of Brazil suffered from low rainfall, causing a serious shortage, especially in the metropolitan region of São Paulo. Judicious strategies for public water supply were adopted, focusing on consumption management, intensification in the leakage control programs and supplying less than $24 \mathrm{~h}$ a day or in less than seven days a week [9]. Brazil has an electrical matrix predominantly from renewable resources $(83.0 \%)$, where the hydro generation corresponded to $64.9 \%$ of the domestic supply [10]. Commonly, the reservoirs of this system have multiple uses, besides water supply. Hence, water shortages can impact not only the public water supply, but also other important sectors of the economy, such as irrigation and power generation in Brazil [2]. 
Considering the Brazilian reality, where the reservoirs of hydroelectric power plants have multiple uses, the water resources management has to cope with a conflict over the use of water, especially in times of water scarcity, if equity has to be granted for all users. Despite the scenario of water scarcity, in Brazil, the non-revenue water in Water Distribution Systems (WDS) reached 39.2\% in 2019. This is the worst result observed in the last 10 years, surpassing the previous value of $38.8 \%$ in 2010, and far from the goals proposed by the government of $34.0 \%$ in 2023 and 31.0\% in 2033 [11]. Water losses also affect the energy consumption of the WDS, since part of the pumped volume could be avoided. In the same year, 2019, the energy consumption for sanitation was 13.26 TWh, which corresponds to $2.4 \%$ of the domestic electricity consumed during that year [10], generating an expenditure of 7.12 billion reais in the year [11]. It is estimated that the annual consumption of electricity by the sector can be reduced by 4.7 TWh through optimized WDS operations: $2.62 \mathrm{TWh}$ could be reduced through the adoption of measures to reduce water losses, and $2.08 \mathrm{TWh}$ by improving the efficiency of pumps and motors [12].

During the last decades, several strategies and tools have been proposed to optimize WDS planning and management, such as pipe sizing [13], sectorization design [14], pump and valve scheduling [15], leakage detection [16], demand forecasting [17], and energy recovery $[18,19]$. The main goal is to ensure that standard requirements are met (e.g., pressure and velocity) at a minimum cost by reducing implantation cost, energy consumption, water losses, etc. Nowadays, the strategies have advanced and take into account more parameters, such as water quality, which are difficult to quantify from their economic benefit perspective, but have a great relevance for the WDS reliability. So, the operation of WDS is designed to match water demand with adequate quantity and quality and can be implemented in two ways: Continuous Water Supply (CWS) and Intermittent Water Supply (IWS). In general, WDS are designed to operate with CWS, $24 \mathrm{~h} /$ day and 7 days/week. However, in some circumstances, one system can start to supply with a lower frequency, thus generating cycles with limited durations, characterized as IWS. IWS can be imposed by a specific cause, usually in a short period as a consequence of a severe drought, or by a combination of multiple factors, which gradually push the system to its limit, and its capacity becomes insufficient to continuously supply the consumers. For example, increased losses, quick population growth, limited water resources, existing infrastructure (precarious or limited), among other aspects, can lead a system to IWS.

As proposed by [20], IWS can significantly reduce the water losses by minimizing the daily distributed volume. Thus, with an operational cost that is economically feasible, IWS can be a reasonable alternative for emergency conditions, such as drought times, to maintain the water resource level and to reduce the overload in reservoirs of hydroelectric power plants with multiple uses, as well. Nonetheless, even being economically feasible, there is a significant increase in the energy consumption and the power required to meet the consumers demand (in terms of daily volume) in a shorter period, while still respecting minimum levels of the WDS hydraulic parameters.

Considering the increasingly worrisome problems due to water scarcity, and the importance of reducing the overload on hydropower reservoirs to achieve equity in the multiple water uses, this paper evaluates a joint strategy for reducing the operating cost through the rehabilitation of main pipes in IWS operation and pump selection and scheduling. This procedure aims to achieve energy reduction of pump stations through a reduction of head losses, which can be significantly higher than those of CWS due to the larger flow necessary to meet the consumers' demand in a shorter period. It is important to highlight that this is a reasonable assumption for the Brazilian systems, as the use of domiciliary reservoirs is common practice. Two case studies are evaluated, both proposed by [20] and with the same hydraulic conditions (e.g., demand pattern, leakage, etc.), so that results can be compared. Firstly, it is necessary to select the main pipes of the systems for rehabilitation and resizing in order to improve the systems' hydraulic parameters (e.g., velocity and head losses) and, consequently, to reduce the power demand. Both pumps' selection and resizing of the main pipes are optimized using Particle Swarm Optimization (PSO). The pumps' rotational 
speed at each time step are also defined during this optimization process, which minimizes the operational costs, represented by the energy consumption, water losses and the resizing of the main pipes. The results show that the energy costs in intermittent operation can significantly be reduced by resizing the main pipes of the network, while still remaining economically feasible. Considering the WDS life cycle, the cost found is lower than those for continuous operation and for the best scenario of intermittency found by [20]. Thus, the approach described herein could be a reasonable alternative to save energy and to reduce the overload in reservoirs, especially with multiple uses. Regions commonly affected by droughts could benefit from implementing the proposed strategy.

\section{Materials and Methods}

The methodology to optimize the IWS operation is based on the minimization of the joint cost function of: (i) operational cost; and (ii) cost for rehabilitation of the main pipes. The first is based on the energy consumption and volume of leaks in the system. The second aims to improve the existing infrastructure (i.e., replacement of pipes with high head loss) in an attempt to optimize the system's efficiency. Figure 1 summarizes the process to achieve the optimal operation. The following sections describe each of the processes presented in Figure 1.

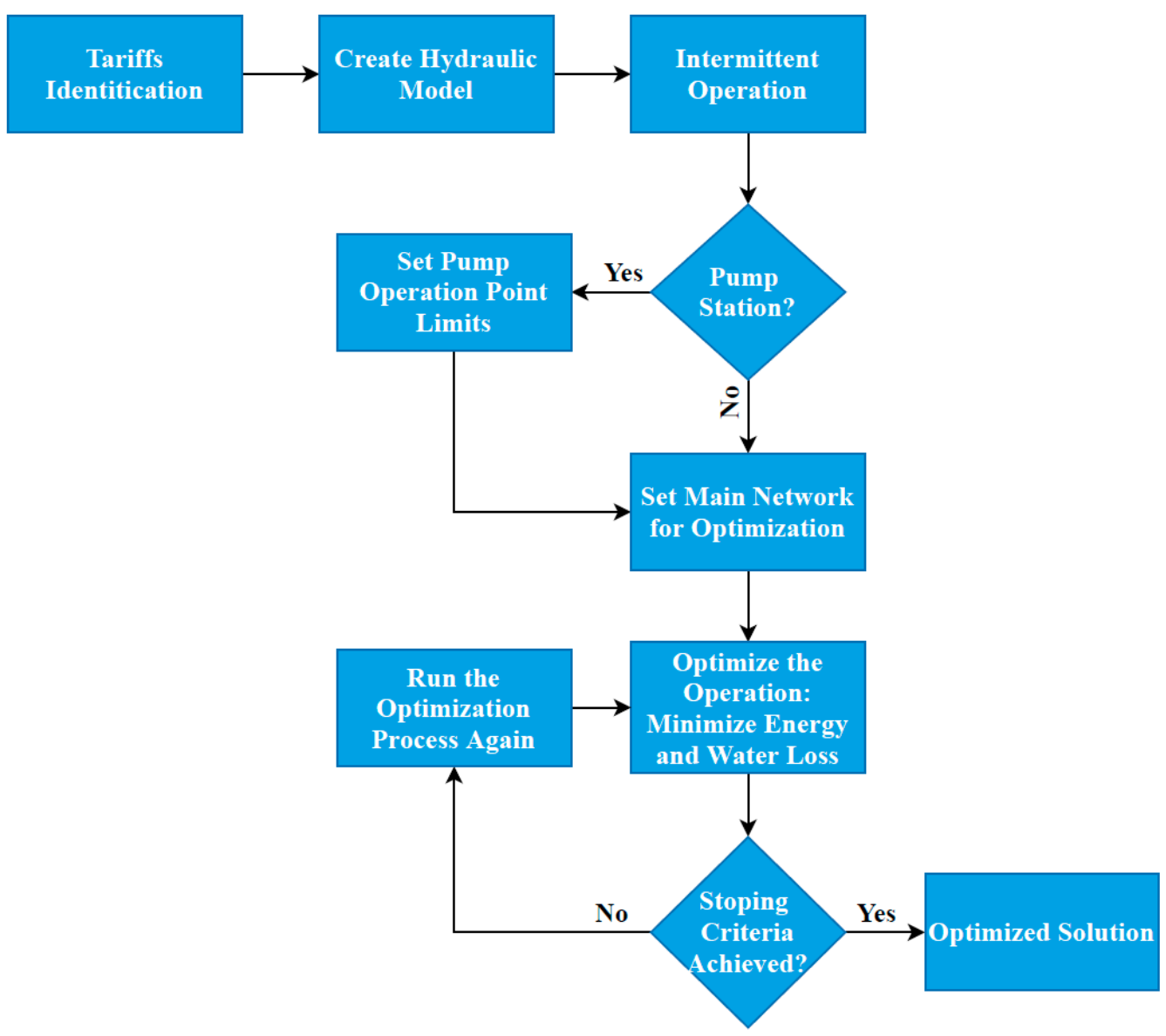

Figure 1. Flowchart of the methodology for optimization of energy consumption. 


\subsection{Pump Selection}

The optimal selection of pumps finds the operating point $(Q$ and $H)$ and the rotation speed $\left(N_{i}\right)$ every hour of the day according to the water consumption pattern, keeping the pump operating as close as possible to the Best Efficiency Point (BEP). Thus, for each pump in the system, there are $t+2$ variables to be optimized, corresponding to the respective rotation speed for each hour of the day and the pair of points in BEP ( $Q_{\mathrm{BEP}}$ and $\left.H_{\mathrm{BEP}}\right)$, where $t$ is the operating horizon.

With the BEP ( $Q_{\mathrm{BEP}}$ and $H_{\mathrm{BEP}}$ ) defined through the optimization, a Single-Point Curve (Figure 2a) is created by Epanet 2.2 [21]. Two estimated points are added to the curve to achieve a function as shown in Equation (1): (i) zero flow and $133 \%$ of $H_{\mathrm{BEP}}$ for shutoff head; and (ii) $200 \%$ of $Q_{\mathrm{BEP}}$ to zero head and maximum flow.

$$
H=a-b \cdot Q^{C}
$$
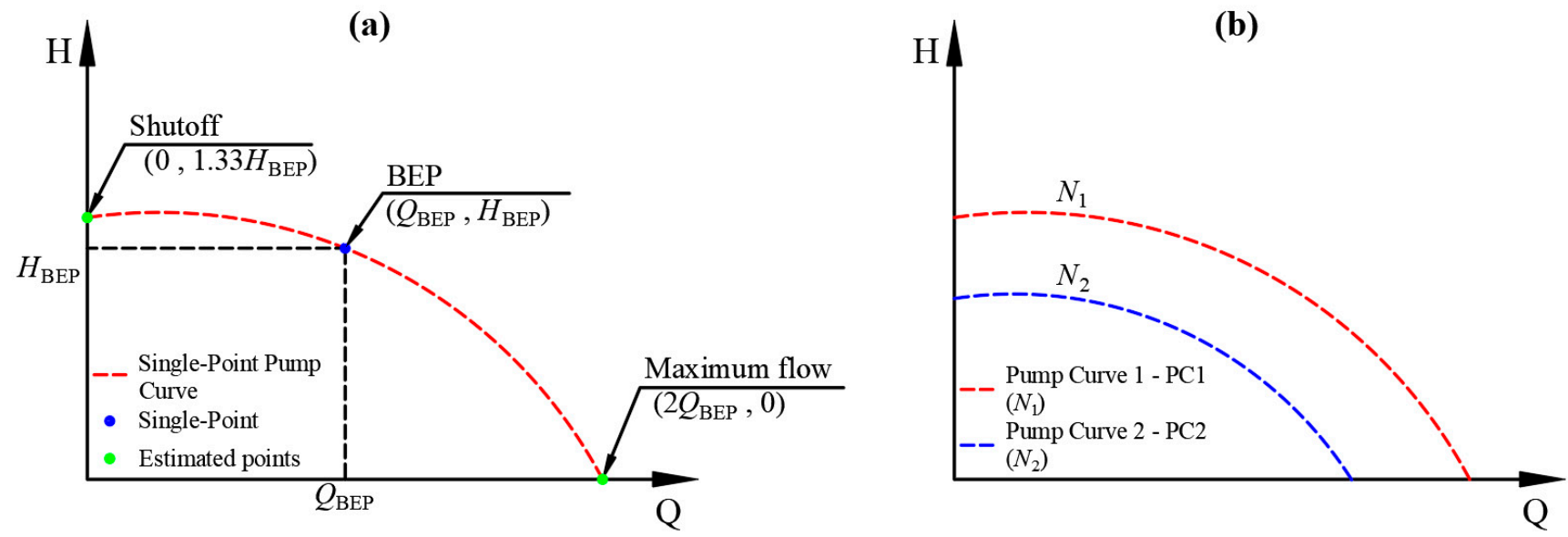

Figure 2. Pump Curve: (a) Single-Point Pump Curve created by Epanet; (b) Variable-Speed Pump Curve.

For each rotational speed, the pump curve shifts as the speed changes (Figure $2 b$ ). The new pump curve can be found from the Single-Point Pump Curve by the relationship between flow $(Q)$ and Head $(H)$ at rotation speeds $N_{1}$ and $N_{2}$ described by the similarity laws, as in Equations (2) and (3) [22].

$$
\begin{gathered}
\frac{Q_{1}}{Q_{2}}=\frac{N_{1}}{N_{2}} \\
\frac{H_{1}}{H_{2}}=\left(\frac{N_{1}}{N_{2}}\right)^{2}
\end{gathered}
$$

Lastly, as proposed by [23] and adopted as a methodology by [20], the pump efficiency can be modelled by a relation between flow $\left(Q_{\mathrm{BEP}}\right)$ and efficiency $\left(\eta_{\mathrm{BEP}}\right)$ at the BEP, as shown in Equation (4) and Figure 3. It is important to highlight that this equation is obtained using the information on pumps available in the Brazilian market [24].

$$
\eta_{\mathrm{BEP}}=12.81 \cdot \operatorname{Ln}\left(Q_{\mathrm{BEP}}\right)+11.62
$$




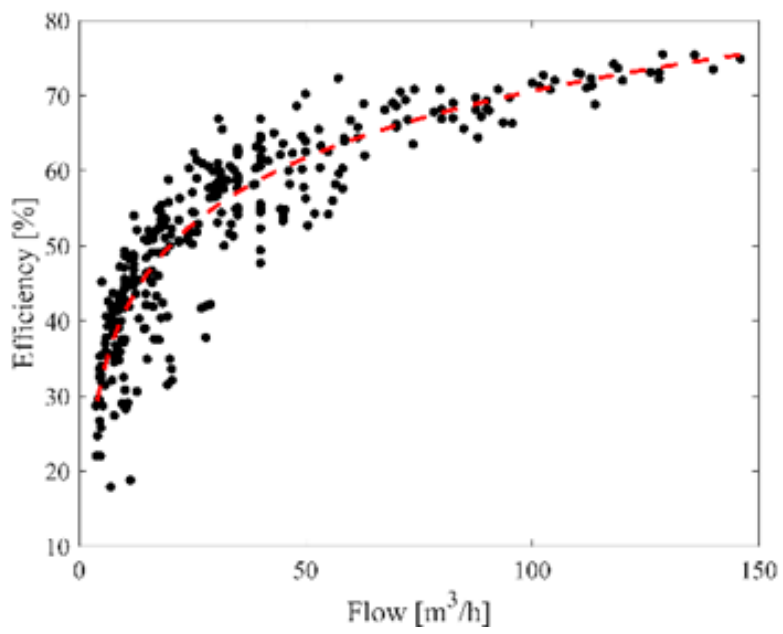

Figure 3. Relation between pump flow and its efficiency at BEP (Source: [23]).

\subsection{Leakage Modeling}

Hydraulic modeling of leakage can be derived from energy conservation, describing the conversion of pressure potential energy into kinetic energy, which results in the wellknown orifice equation. According to the one orifice equation, the leakage flow $\left(Q_{L}\right)$ is proportional to the square root of the pressure differential $(h)$ over the leakage orifice, described as Equation (5), where $C_{d}$ is the discharge coefficient, $A$ the leak area and $g$ the acceleration due to gravity.

$$
Q_{L}=C_{d} \cdot A \cdot \sqrt{2 \cdot g \cdot h}
$$

Nonetheless, it is difficult to measure the value of the leak area $(A)$, which can assume different values for different pressure ranges [25]. Therefore, Equation (5) is rewritten as a potential equation of generalized use in water supply given by Equation (6), where $\alpha$ is the leakage coefficient and $\beta$ the leakage exponent.

$$
Q_{L}=\alpha \cdot h^{\beta}
$$

The leakage exponent ( $\beta$ ) of Equation (6) is an empirical variable to be determined according to the hydraulic characteristics of each system and can vary between 0.36 and 2.95 [26], different from the constant value of 0.5 used in the orifice equation [27]. The leakage coefficient $(\alpha)$ can be calibrated to achieve the leakage volume of the systems. So, the Epanet 2.2 can model the leakage flow by associating Equation (6) to each node of the network model. The daily leakage volume $(D L)$ can be estimated by multiplying Equation (6) by the time step $(\Delta t)$ until reaching the total operating time $(t)$ to be simulated up to the $n$th node of the system, given in Equation (7).

$$
D L=\sum_{j=1}^{n} \sum_{i=1}^{t} Q_{L_{n, i}} \cdot \Delta t
$$

\subsection{Main Network Modeling}

According to [28], the main network corresponds to the pipes of the water distribution network (WDN) with larger diameters, which supply the other smaller diameter pipes responsible for supplying the consumption points. It is important to define the main network to be able to select some of its pipes and resize them. As larger pipes, they can transport larger flows, which can be significantly increased in IWS in order to supply the same volume in a shorter period. As a result, head losses are also increased, thus affecting the pumping energy consumption and possibly creating pressure problems, since the effects observed in the main pipes can affect the entire network. So, the system's resizing consists of replacing some or all pipes of the main network in order to improve the system's 
hydraulic parameters (e.g., velocity and head losses) and, therefore, to reduce the power demand in pump stations.

Several parameters can be used to determine the main network of the WDN, such as pipe diameter, number of connections, and geographic position in the system. However, in complex systems, large ones and/or those with multiple sources of supply, the visualization of the main network is not clear and its determination becomes a complex task. In this regard, [29] uses graph theory to distinguish the levels of importance of each pipe and to determine the main network. The graph theory is a branch of mathematics dedicated to the study of structures integrated by vertices interconnected by edges. WDN have been modelled as graphs [30-34], where the nodes are represented by the vertices and the links by the edges.

As proposed by [29], by knowing the direction of the flows within the pipes, it is possible to calculate the Accumulated Shortest Path Value (ASPV). The ASPV represents the shortest path for water to reach node $N_{F}$ flowing from node $N_{I}$. The ASPV is calculated for each pair of the $n$ nodes of the network $\left(N_{I}\right.$ and $\left.N_{F}\right)$ and compiled in an $n \times n$ matrix, as in Equation (8), where the rows represent the initial nodes $\left(N_{I}\right)$ and the columns the final nodes $\left(N_{F}\right)$. After calculating the $A S P V$ for each pair of nodes, each element of $A S P V$ matrix is weighted by the flow of the element linking both nodes, resulting in a new matrix $\left(A S P V^{*}\right)$. In this way, pipes with small diameters and flow rates, which have small relevance to the hydraulic behavior of the system, are disregarded from the main network. Finally, it is possible to visualize the number of nodes/pipes that can be reached from each node, as well as sort them out by importance, where the pipes with higher $A S P V^{*}$ values are more relevant for the system.

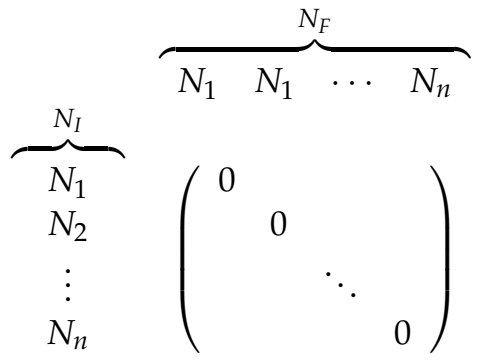

Still, according to [29], the main network is integrated by the pipes with high values of $A S P V^{*}$, which have a low relative frequency, while the secondary network pipes exhibit low values of $A S P V^{*}$ with high relative frequencies. Also, according to [29], approximately $80 \%$ of the pipes have high relative frequency and must be classified within the secondary network, while the remaining $20 \%$ integrate the main network. In this study, also $20 \%$ of higher $A S P V^{*}$ value pipes are considered as belonging to the main network.

\subsection{Cost Modeling}

The hydraulic results of each simulation (leakage and energy consumption) must be transformed into an operational cost by a cost function to be optimized (minimized). So, the cost parameters (hydraulic and energy tariffs) are very important, as they can make a solution more or less economically attractive. Table 1 shows the values of the electrical tariffs (Energy tariff $t e$ and power tariff $t p$ ) corresponding to the values of the hourly green tariff (wet period and green flag) practiced by Companhia Energética de Minas GeraisCEMIG (Minas Gerais Energy Company, Minas Gerais, Brazil) and, also adopted by [20] for coverage of the study site, Minas Gerais. The peak hours $(\mathrm{PH})$ were defined, also according to coverage, as the period between 5:00 p.m. and 7:00 p.m. and the other times as non-peak hours (NPH). Table 2 shows the average total expenditure amounts (IN003) of service providers participating in the Sistema Nacional de Informações sobre Saneamento-SNIS (National Sanitation Information System), in 2018, according to coverage. According to [11], the IN003 indicator reveals how much is spent per cubic meter of water billed. 
Table 1. Energy Tariff Values.

\begin{tabular}{cc}
\hline Description & Tariff \\
\hline Energy-non-peak hour $(\mathrm{NPH})(\mathrm{R} \$ / \mathrm{kWh})$ & 0.3567 \\
Energy-peak hour $(\mathrm{PH})(\mathrm{R} \$ / \mathrm{kWh})$ & 0.5342 \\
Power-non-peak hour $(\mathrm{NPH})(\mathrm{R} \$ / \mathrm{kW})$ & 13.950 \\
Power-peak hour $(\mathrm{PH})(\mathrm{R} \$ / \mathrm{kW})$ & 43.950 \\
\hline
\end{tabular}

Source: [35].

Table 2. Water production tariff.

\begin{tabular}{ccc}
\hline Description & $\begin{array}{c}\text { Range of Average Total } \\
\text { Expenditure Amounts (IN003) } \\
\left(\mathbf{R} \$ \mathbf{m}^{3} \mathbf{)}\right.\end{array}$ & $\begin{array}{c}\text { Average Total Expenditure } \\
\text { Amounts (IN003) } \\
\left(\mathbf{R} \$ \mathbf{m} \mathbf{m}^{3}\right)\end{array}$ \\
\hline $\begin{array}{c}\text { Regional } \\
\text { Micro-regional }\end{array}$ & 1.87 to 7.61 & 3.96 \\
Local & 1.05 to 5.53 & 3.48 \\
Brazil & 0.30 to 7.82 & 2.68 \\
\hline
\end{tabular}

Source: [11].

It is clear the high variation in the water production tariff $(t w)$ according to the coverage in Brazil, as shown in Table 2. Therefore, in this paper, three different scenarios are studied: scenarios 1 and 2 correspond, respectively, to the minimum and maximum values of the average total expenditure in Brazil, of $0.30 \mathrm{R} \$ / \mathrm{m}^{3}$ and $7.82 \mathrm{R} \$ / \mathrm{m}^{3}$; and, for scenario 3 , the value of the average total expense of Brazil of $3.57 \mathrm{R} \$ / \mathrm{m}^{3}$ is used. Thus, scenarios 1 and 2 correspond to extreme values, while scenario 3 to the average value.

It is important to highlight that the tariff values and scenarios studied in this paper refer to the same ones adopted by [20] for comparison reasons.

\subsection{Optimization Procedure}

The optimization of the system consists of replacing some pipes of the distribution network and the selection of pumps in order to improve the system's hydraulic parameters and, therefore, reduce operating costs. However, it is necessary to carry out an economic evaluation, since the cost of implementing new pipes and/or pumps represents a high monetary impact in the short term, but is diluted over the WDS life cycle, and can be surpassed by the improvements made in the operational efficiency.

The annual operating costs of the WDS life cycle are translated into a single payment according to the economic concept of Present Value $(P V)$ [36] through the Present Value Factor $(P V F)$. The PVF can be observed in Equation (9), where the project horizon ( $p h)$, was defined as 30 years, with an average interest rate (ir), of $12 \%$ p.a., common values used for the Brazilian reality.

$$
P V F=\frac{(1+i r)^{p h}-1}{i r \cdot(1+i r)^{p h}}
$$

Equation (10) describes the Objective Function $(O F)$ to be minimized, in which the daily operating costs $\left(C_{0}\right.$, Equation (12)) of the project horizon are translated into a single payment by $P V F$, and added to the acquisition and installation costs of pipes and pumps $\left(C_{i}\right.$, Equation (11)). The implementation costs are obtained from Brazilian bases [37-39].

$$
\begin{gathered}
\text { OF }=C_{o} \cdot 365 \cdot P V F+C_{i}+P e n \\
C_{i}=\sum_{j=1}^{N l} C P_{D, i} \cdot L_{i}+\sum_{b=1}^{N p} C_{P M, b} \\
C_{o}=\sum_{p=1}^{N p} \sum_{i=1}^{t}\left[\frac{\gamma \cdot Q_{i} \cdot H_{i}}{1000 \cdot \eta_{i}} \cdot t e_{i}\right]+\sum_{p=1}^{n p} P_{\text {max }} \cdot t p_{i}+\sum_{i=1}^{t}[D L \cdot t w]
\end{gathered}
$$


where:

OF $(\mathrm{R} \$)$-objective function to be minimized;

$C_{o}(\mathrm{R} \$)$ - daily operating cost;

$P V F$ (dimensionless) - present value factor;

$C_{i}(\mathrm{R} \$)$-implementation cost;

$\mathrm{Nl}$ (dimensionless) - number of links of main network;

$C P_{D, i}(\mathrm{R} \$ / \mathrm{m})$-linear cost of implantation of the pipe $i$ and diameter $D$;

$N p$ (dimensionless)—number of pumps operating in the network;

$C_{P M, b}(\mathrm{R} \$)$ - cost of the implantation of the pump and motor $b$;

$t$ (h) 一total time simulation;

$\gamma\left(\mathrm{N} / \mathrm{m}^{3}\right)$-specific weight of water;

$Q_{i}\left(\mathrm{~m}^{3} / \mathrm{s}\right)$ - pump flow at time $i$;

$H_{i}(\mathrm{~m})$ - pump head at time $i$;

$\eta_{i}$ (dimensionless) - pump efficiency at time $i$;

te $e_{i}(\mathrm{R} \$ / \mathrm{kWh})$ - energy tariff at time $i$;

$P_{\text {max }}(\mathrm{kW})$-maximum power;

$t p_{i}(\mathrm{R} \$ / \mathrm{kW})$ - power tariff at time $i$;

$D L\left(\mathrm{~m}^{3}\right)$-daily leakage;

$t w(\mathrm{R} \$ / \mathrm{kW})$-water production tariff;

Pen (R\$)-penalty function.

Finally, the penalty, presented in Equation (13), aims to deal with system constraints so that the optimized result is technically feasible. In this study, only the minimum pressure $\left(p_{\min }\right)$ of $10 \mathrm{~m}$ is adopted as recommended in [28]. The penalty coefficient $(\epsilon)$ adopted was $10^{8}$, a value tested and verified to quickly disregard solutions that violate the restriction. Equation (13) mathematically demonstrates the penalty due to violation of the adopted minimum pressure constraint, where $p_{j, i}$ is the pressure at node $j$ at time $i$ and $n_{\text {pen }}$ represents the number of nodes with pressures lower than the minimum pressure $p_{\text {min }}$.

$$
\text { Pen }=\sum_{i=0}^{n_{\text {pen }}} \epsilon \cdot\left|p_{\text {min }}-p_{j, i}\right|
$$

For finding the optimal solution, Particle Swarm Optimization (PSO) algorithm is applied. PSO was proposed by Eberhart and Kennedy in 1995 and consists of mimicking the collective response observed in flocks of birds [40,41].

The positions $(X)$ of the particles represent the possible solutions to the problem, and their displacement occurs in search of the best position within the group. Basically, the particles move in the space searching for the best solution with a velocity $(V)$. Positions $(X)$ are randomly initialized and provide the starting iteration solution. In the next iterations, a particle trajectory evolves based on the own experience and on the collective experience. It happens through three components, namely: (i) inertia coefficient $(\omega)$ : trend of the particle following its movement; (ii) cognitive coefficient $\left(c_{1}\right)$ : best position ever occupied by the particle; and (iii) social coefficient $\left(c_{2}\right)$ : best position ever occupied by any particle of the group. Equations (14) and (15) describe mathematically the search process, where the coefficients rand $_{1}$ and rand $_{2}$ represent uniformly random distributed values $\epsilon[0,1]$ to assign randomness to the process, in order to increase diversity, trying to cover the entire search space, and avoid premature convergence to local minima in search process.

$$
\begin{gathered}
V_{i}^{t+1}=\omega \cdot V_{i}^{t}+c_{1} \cdot \operatorname{rand}_{1} \cdot \frac{\left(X p_{i}^{t}-X_{i}^{t}\right)}{\Delta t}+c_{2} \cdot \operatorname{rand}_{2} \cdot \frac{\left(X g-X_{i}^{t}\right)}{\Delta t} \\
X_{i}^{t+1}=X_{i}^{t}+V_{i}^{t+1} \cdot \Delta t
\end{gathered}
$$

In this work, the inertia coefficient $(\omega)$ was set to 1.1 and the cognitive $\left(c_{1}\right)$ and social $\left(c_{2}\right)$ coefficients were set to 1.49 , which are the values defined as default in the MATLAB ${ }^{\circledR}$ software. The stopping criteria, with a number of particles adopted equal to 100 , tested and proven to obtain optimized solutions, were: (i) a maximum number of 
1000 iterations; or (ii) variation of the objective function equal to or less than $10^{-10}$ for 20 consecutive times.

\section{Case Studies}

The case studies are the benchmark ZJ and OBCL-1 networks, both part of the database of a series of benchmarking networks of [42], and are the same ones studied by [20]. The first one, the ZJ network, is a model of Zhijiang City, located in the west of Hubei Province in China, and OBLC-1 is a model of the Oberlin community located in the city of Harrisburg, Pennsylvania, northeastern United States.

To better compare the results and visualize the improvements with the methodology proposed in this paper, the most efficient intermittent level for each case study found by [20] was adopted. Furthermore, the same demand pattern and leakage coefficients and exponent $(\alpha$ and $\beta$ ) were used.

\subsection{Case Study 1: ZJ Network}

The ZJ network is a model with 114 nodes and 164 pipes totaling approximately $126 \mathrm{~km}$ of the existing infrastructure supplied by gravity from a reservoir. Thus, only leakage is considered to calculate the operational costs. The leakage and exponent coefficients $(\alpha$ and $\beta$ ) are set as 0.65 and 0.5 , respectively, for all nodes, and the daily demand is $110,870 \mathrm{~m}^{3}$. Figure 4 shows the ZJ infrastructure and its main pipes defined ( $20 \%$ of the total existing length-25.2 km).

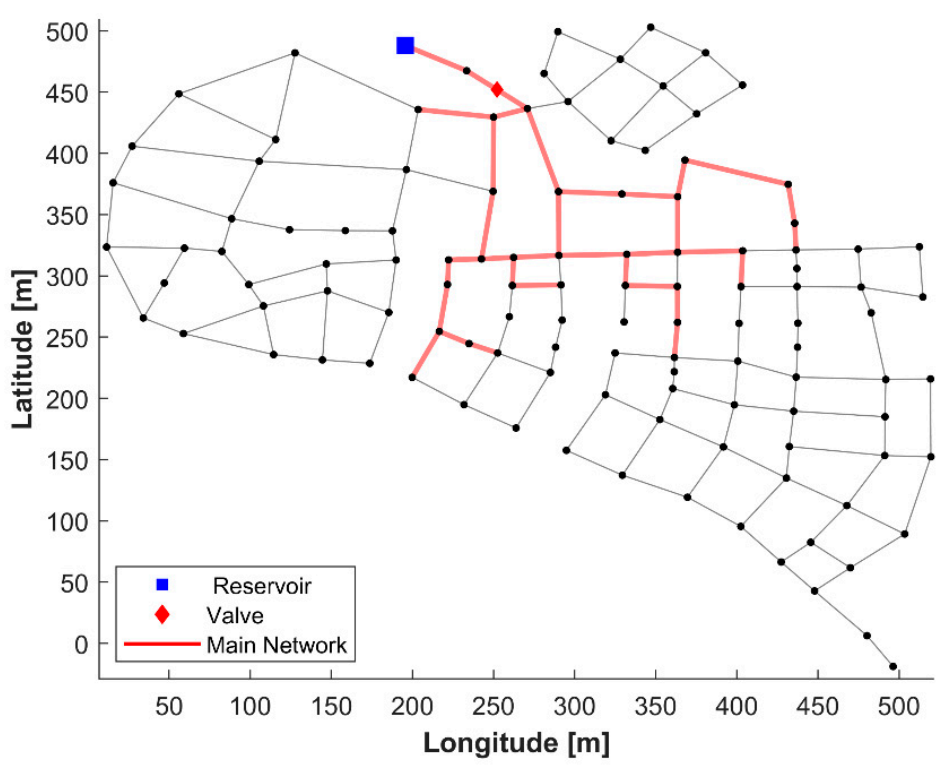

Figure 4. ZJ Network.

\subsection{Case Study 2: OBCL-1 Network}

The OBCL-1 network is a model with 269 nodes and 294 pipes totaling around $60 \mathrm{~km}$ of the existing infrastructure supplied from a reservoir by a pump station. The leakage and exponent coefficients $(\alpha$ and $\beta$ ) are set as 0.03 and 0.5 , respectively, for all nodes, and the daily demand is $14,270 \mathrm{~m}^{3}$. Figure 5 shows the OBCL-1 infrastructure and its main network defined $(20 \%$ of the total- $12.0 \mathrm{~km})$. 


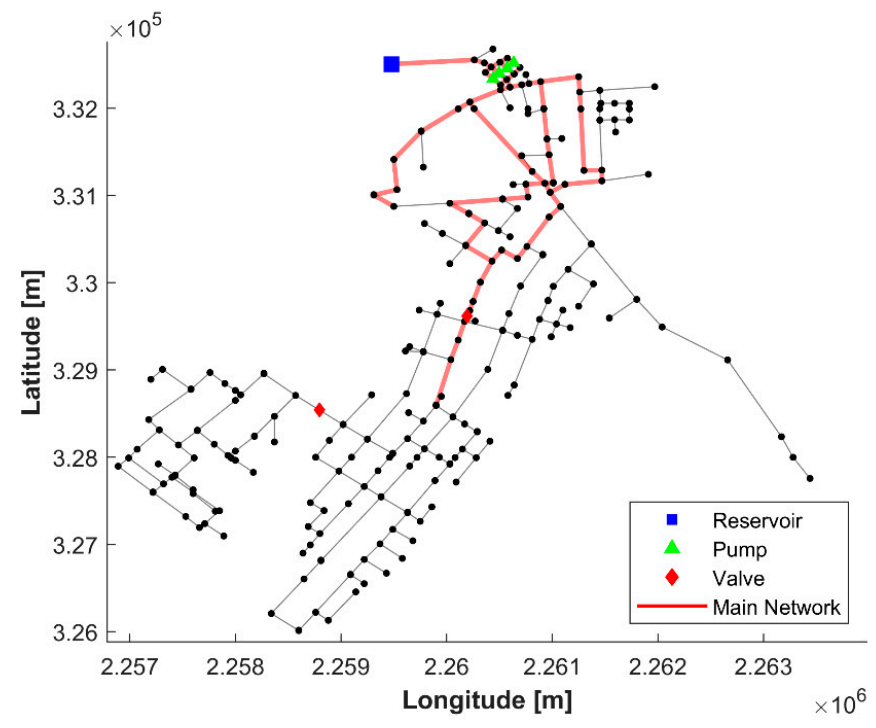

Figure 5. OBCL-1 Network.

\section{Results}

\subsection{ZJ Network Results}

Table 3 shows a comparison of the hydraulic and economic parameters for the CWS, the IWS optimized operation proposed by [20], and the IWS optimized operation with the resizing of the main network. The economic efficiency $(E)$ is calculated according to Equation (16), where $P O C_{24 h}$ and $P O C_{t}$ are the project horizon cost of the CWS and IWS scenarios, respectively.

$$
E=\frac{P O C_{24 h}-P O C_{t}}{P O C_{24 h}} \cdot 100
$$

Table 3. Comparison of hydraulic and economic parameters for the different scenarios studied in the ZJ network.

\begin{tabular}{|c|c|c|c|c|c|c|c|c|c|c|c|c|}
\hline \multirow[b]{2}{*}{ Description } & \multicolumn{4}{|c|}{$t w=0.30 \mathrm{R} \$ / \mathrm{m}^{3}$} & \multicolumn{4}{|c|}{$t w=7.82 \mathrm{R} \$ / \mathrm{m}^{3}$} & \multicolumn{4}{|c|}{$t w=3.50 \mathrm{R} \$ / \mathrm{m}^{3}$} \\
\hline & $24 \mathrm{~h}^{1}$ & $15 h^{1}$ & $12 \mathrm{~h}^{1}$ & $12 \mathrm{~h} *$ & $24 \mathrm{~h}^{1}$ & $15 h^{1}$ & $12 \mathrm{~h}^{1}$ & $12 \mathrm{~h}$ * & $24 h^{1}$ & $15 h^{1}$ & $12 \mathrm{~h}^{1}$ & $12 \mathrm{~h}$ * \\
\hline Mean pressure (m) & 55 & 22 & 4 & 33 & 55 & 22 & 4 & 33 & 55 & 22 & 4 & 33 \\
\hline Daily distribution $\left(10^{3} \mathrm{~m}^{3}\right)$ & 158.1 & 129.6 & - & 129.1 & 158.1 & 129.6 & - & 129.1 & 158.1 & 129.6 & - & 129.1 \\
\hline Daily consumption $\left(10^{3} \mathrm{~m}^{3}\right)$ & 110.9 & 110.9 & - & 110.9 & 110.9 & 110.9 & - & 110.9 & 110.9 & 110.9 & - & 110.9 \\
\hline Daily leakage $\left(10^{3} \mathrm{~m}^{3}\right)$ & 47.2 & 18.7 & - & 18.2 & 47.2 & 18.7 & - & 18.2 & 47.206 & 18.7 & - & 18.2 \\
\hline Daily leakage (\%) & 29.9 & 14.5 & - & 14.1 & 29.9 & 14.5 & - & 14.1 & 29.9 & 14.5 & - & 14.1 \\
\hline Daily energy cost $\left(10^{3} \mathrm{R} \$\right)$ & - & - & - & - & - & - & - & - & - & - & - & - \\
\hline Daily leakage cost $\left(10^{3} \mathrm{R} \$\right)$ & 14.2 & 5.6 & - & 5.5 & 369.1 & 146.5 & - & 142.6 & 168.5 & 66.9 & - & 65.1 \\
\hline Implantation cost $\left(10^{6} \mathrm{R} \$\right)$ & - & - & - & 4.9 & - & - & - & 4.9 & - & - & - & 4.9 \\
\hline Project horizon cost $\left(10^{6} \mathrm{R} \$\right)$ & 41.6 & 16.5 & - & 21.0 & 1085.3 & 430.8 & - & 424.1 & 495.5 & 196.7 & - & 196.3 \\
\hline Economic efficiency (\%) & - & 60.3 & - & 49.6 & - & 60.3 & - & 60.9 & - & 60.3 & - & 60.4 \\
\hline
\end{tabular}

${ }^{1}$ Source: [20]. * Optimized scenarios.

As the supply is made by gravity, the resizing of the WDN in intermittent operation is an alternative to operate within a lower number of hours and guarantee the minimum pressure. The best solution found by [20] is an IWS of $15 \mathrm{~h}$. When the $12 \mathrm{~h}$ scenario was simulated, pressure dropped below the minimum required, as shown in Figure 6. Thus, to achieve the minimum pressure of $10 \mathrm{~m}$, as recommended in [28], it is necessary to resize the first pipe (next to the reservoir), with a length of $2013 \mathrm{~m}$, due to the excessive velocity observed, and, consequently, high head loss. Despite this resizing, the velocity is still excessively high, around $6.0 \mathrm{~m} / \mathrm{s}$ (Figure 7), wherein it must be around $3.0 \mathrm{~m} / \mathrm{s}$, according to [28], to avoid wear of pipes and valves, noises, and higher danger with transient regime due to high velocity. However, this is an infrastructure problem, since, both for the CWS 
and IWS of $15 \mathrm{~h}$, the velocity is higher than $6.0 \mathrm{~m} / \mathrm{s}$ (Figure 7); so, attention to operation and/or interventions to correct this problem must be considered at any level of operation.
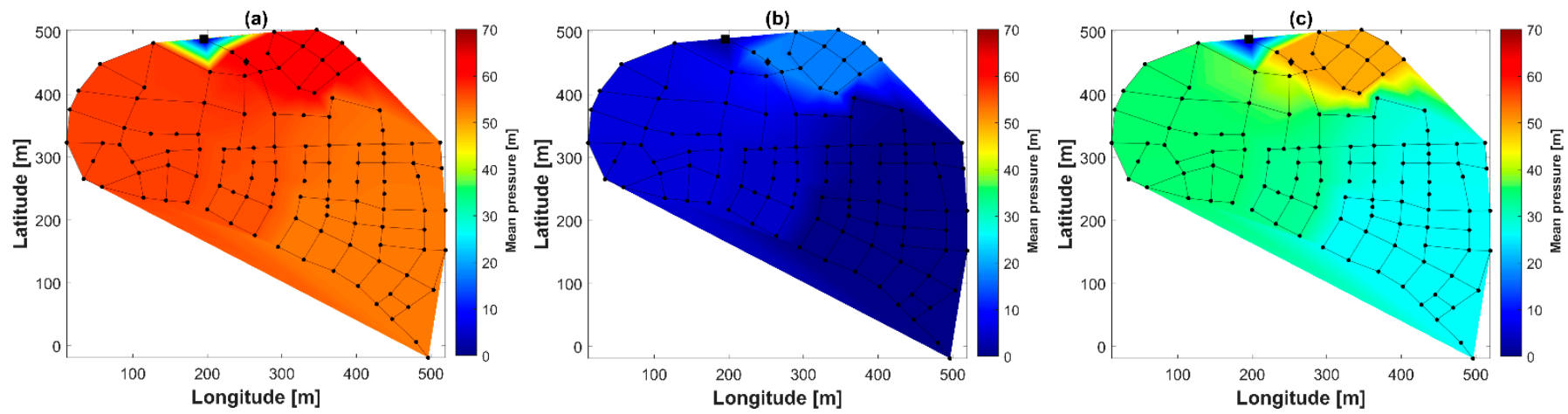

Figure 6. Mean pressure for the ZJ network: (a) 24 h; (b) 12 h; (c) 12 h optimized.
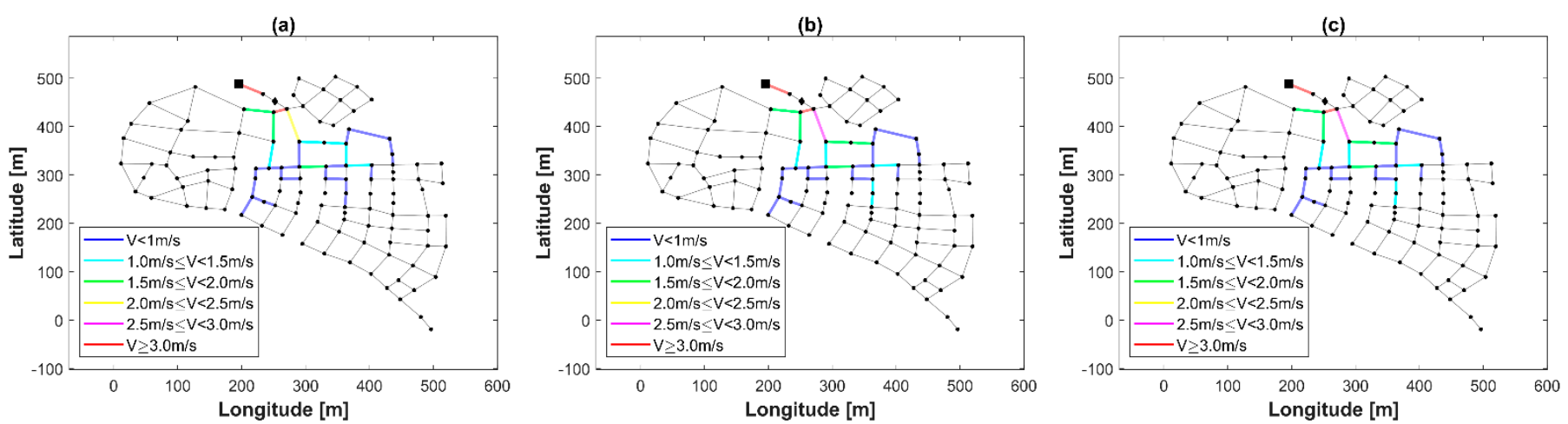

Figure 7. Velocity in the main network pressure for the ZJ network: (a) 24 h; (b) 12 h; (c) 12 h optimized.

The IWS of $12 \mathrm{~h}$ shows a daily leakage of $14.1 \%$, only $0.4 \%$ lower than the best-case scenario found by [20] for the IWS of $15 \mathrm{~h}$. The reduction in actual leakage is not expressive with the decrease in the number of hours of operation from $15 \mathrm{~h}$ to $12 \mathrm{~h}$ due to the increase in mean pressure. Since the IWS of the $15 \mathrm{~h}$ scenario has the original pipes, the velocity above $6.0 \mathrm{~m} / \mathrm{s}$ in pipes close to the reservoir worked as a pressure regulator in the system, providing an average pressure of $22 \mathrm{~m}$. When the resizing is done for the IWS of the $12 \mathrm{~h}$ scenario, the diameter of the first pipe increases from $700 \mathrm{~mm}$ to $800 \mathrm{~mm}(+14.3 \%)$. So, a slight decrease in velocity is observed, but the average pressure increased to $33 \mathrm{~m}$. In this case, the implementation of a Pressure Reducing Valve (PRV) could contribute even more to reduce leakage. Also, pump as turbines (PATs) could achieve better results as it could be an alternative to convert the excess of energy (pressure) into electricity. So, besides limiting the system pressure and reduce leakage, PATs could generate electricity, as highlighted by $[18,19]$. Neither PRVs nor PATs are implemented in this work. Despite this, it is emphasized again that the role played by pipes in controlling the pressure, due to excessive velocity and head loss, is concerning from the point of view of the physical safety of the system, being a function of PRVs or PATs.

From an economic point of view, the resizing cost is 4.9 million reais. As this is a very expensive procedure, its feasibility is highly sensitive to the water production tariff, tw. Thus, for the lowest tariff, even with an economic efficiency of $49.6 \%$ over the CWS, the IWS of $15 \mathrm{~h}$ is still the best option, with an economic efficiency of $60.3 \%$. In scenarios 2 and 3, where the production tariff is higher, the implementation cost is less representative, resulting in an economic efficiency of $60.9 \%$ and $60.4 \%$, respectively, slightly higher than that observed for the same scenarios with the $15 \mathrm{~h}$ operation. 


\subsection{OBCL-1 Network Results}

In this case study, the resizing of the WDN in intermittent operation is an alternative to reduce the energy cost for the best IWS solution $(15 \mathrm{~h})$ found by [20], as well as a possible improvement for an IWS operation with fewer hours $(12 \mathrm{~h})$. The resized extensions for each scenario are presented in Table 4, and the results obtained from the hydraulic simulation of the optimized scenario have been compared with the results obtained by [20] in Table 5 .

Table 4. Resized extensions for each scenario in the OBCL-1 network.

\begin{tabular}{|c|c|c|c|c|c|c|}
\hline \multirow[b]{2}{*}{ Description } & \multicolumn{2}{|c|}{$t w=0.30 \mathrm{R} \$ / \mathrm{m}^{3}$} & \multicolumn{2}{|c|}{$t w=7.82 \mathrm{R} \$ / \mathrm{m}^{3}$} & \multicolumn{2}{|c|}{$t w=3.50 \mathrm{R} \$ / \mathrm{m}^{3}$} \\
\hline & $15 \mathrm{~h}$ * & $12 \mathrm{~h}$ * & $15 \mathrm{~h} *$ & $12 \mathrm{~h}$ * & $15 \mathrm{~h}$ * & $12 \mathrm{~h}$ * \\
\hline Resized extensions (m) & 10,626 & 9513 & 9727 & 10,671 & 11,741 & 12,057 \\
\hline
\end{tabular}

Table 5. Comparison of hydraulic, energy and economic parameters for the different scenarios studied in the OBCL-1 network.

\begin{tabular}{|c|c|c|c|c|c|c|c|c|c|c|c|c|c|c|c|}
\hline \multirow[b]{2}{*}{ Description } & \multicolumn{5}{|c|}{$t w=0.30 \mathrm{R} \$ / \mathrm{m}^{3}$} & \multicolumn{5}{|c|}{$t w=7.82 \mathrm{R} \$ / \mathrm{m}^{3}$} & \multicolumn{5}{|c|}{$t w=3.50 \mathrm{R} \$ / \mathrm{m}^{3}$} \\
\hline & $24 h^{1}$ & $15 \mathrm{~h}^{1}$ & $15 \mathrm{~h}$ * & $12 \mathrm{~h}^{1}$ & $12 \mathrm{~h}^{*}$ & $24 \mathrm{~h}^{1}$ & $15 \mathrm{~h}^{1}$ & $15 \mathrm{~h}^{*}$ & $12 \mathrm{~h}^{1}$ & $12 \mathrm{~h}$ * & $24 \mathrm{~h}^{1}$ & $15 \mathrm{~h}^{1}$ & $15 \mathrm{~h} *$ & $12 \mathrm{~h}^{1}$ & $12 \mathrm{~h}$ * \\
\hline Power-PH (kW) & 35 & 67 & 10 & 211 & 14 & 41 & 71 & 18 & 199 & 14 & 36 & 70 & 17 & 211 & 9 \\
\hline Energy-PH (kWh) & 92 & 180 & 29 & 416 & 41 & 97 & 181 & 33 & 417 & 34 & 94 & 173 & 43 & 416 & 19 \\
\hline Power-NPH (kW) & 54 & 182 & 41 & 261 & 22 & 33 & 180 & 33 & 258 & 22 & 66 & 180 & 32 & 262 & 19 \\
\hline Energy-NPH (kWh) & 489 & 1063 & 253 & 1272 & 148 & 512 & 1046 & 117 & 1250 & 99 & 463 & 1080 & 224 & 1410 & 100 \\
\hline Total Energy ( $\mathrm{kWh}$ /day) & 581 & 1243 & 282 & 1689 & 189 & 608 & 1227 & 150 & 1668 & 134 & 556 & 1253 & 267 & 1825 & 120 \\
\hline Mean pressure (m) & 82 & 84 & 74 & 85 & 79 & 80 & 82 & 73 & 84 & 68 & 81 & 81 & 77 & 81 & 67 \\
\hline Daily distribution $\left(10^{3} \mathrm{~m}^{3}\right)$ & 20.2 & 18.1 & 17.8 & 17.3 & 17.2 & 20.1 & 18.0 & 17.7 & 17.3 & 17.0 & 20.1 & 18.0 & 17.8 & 17.2 & 16.9 \\
\hline Daily consumption $\left(10^{3} \mathrm{~m}^{3}\right)$ & 14.3 & 14.3 & 14.3 & 14.3 & 14.3 & 14.3 & 14.3 & 14.3 & 14.3 & 14.3 & 14.3 & 14.3 & 14.3 & 14.3 & 14.3 \\
\hline Daily leakage $\left(10^{3} \mathrm{~m}^{3}\right)$ & 5.9 & 3.8 & 3.5 & 3.1 & 2.9 & 5.8 & 3.7 & 3.5 & 3.1 & 2.7 & 5.8 & 3.7 & 3.6 & 2.9 & 2.7 \\
\hline Daily leakage $(\%)$ & 29.3 & 21.0 & 19.8 & 17.7 & 16.9 & 28.9 & 20.7 & 19.5 & 17.7 & 15.8 & 29.0 & 20.7 & 20.0 & 17.1 & 15.8 \\
\hline Daily energy $\operatorname{cost}\left(10^{3} R \$\right)$ & 2.5 & 5.9 & 1.1 & 13.6 & 1.0 & 2.5 & 6.1 & 1.3 & 13.0 & 1.0 & 2.7 & 6.1 & 1.3 & 13.6 & 0.7 \\
\hline Daily leakage cost $\left(10^{3} \mathrm{R} \$\right)$ & 1.8 & 1.1 & 1.1 & 0.9 & 0.9 & 45.6 & 29.2 & 27.0 & 24.0 & 21.0 & 20.8 & 13.3 & 12.8 & 10.5 & 9.5 \\
\hline Implantation cost $\left(10^{6} \mathrm{R} \$\right)$ & - & - & 5.0 & - & 5.4 & - & - & 7.2 & - & 9.6 & - & - & 7.8 & - & 8.4 \\
\hline Project horizon cost $\left(10^{6} \mathrm{R} \$\right)$ & 12.7 & 21.0 & 11.4 & 43.0 & 10.9 & 141.3 & 103.9 & 90.5 & 109.3 & 74.3 & 69.3 & 57.2 & 49.0 & 71.4 & 38.5 \\
\hline Efficiency $(\%)$ & - & -65.8 & 10.0 & -239.5 & 14.0 & - & 26.4 & 36.0 & 22.7 & 47.4 & - & 17.5 & 29.2 & -3.1 & 44.5 \\
\hline
\end{tabular}

${ }^{1}$ Source: [20]. * Optimized scenarios.

It is observed that the resizing (implementation/replacement) of $9513 \mathrm{~m}(15.8 \%)$ up to $12,057 \mathrm{~m}(20.0 \%)$ of the main conduit of a total of approximately $60 \mathrm{~km}$ of the existing infrastructure is necessary. The increase in velocity due to the intermittent regime is corrected by replacing some pipes in the main network and, only isolated points presented velocity above $2.0 \mathrm{~m} / \mathrm{s}$, as shown in Figure 8 . Thus, there is a significant reduction in both power demand $(\mathrm{kW})$ and energy consumption $(\mathrm{kWh})$ in the optimized intermittency scenarios with resizing $\left(15 \mathrm{~h}^{*}\right.$ and $\left.12 \mathrm{~h}^{*}\right)$ when compared to the scenarios with the same level of intermittency, but without any intervention in the infrastructure ( $15 \mathrm{~h}$ and $12 \mathrm{~h}$ ). The reduction of energy parameters is due to the selection of pumps with lower head $\left(H_{B E P}\right)$. This is possible due to the reduction in head loss of the new pipes, achieved from two aspects: (i) correction of high velocities; and (ii) correction of the low Hazen-Williams coefficient for old pipes. In addition, the smaller head of the pump also reduced the daily distribution and mean pressure, as also shown in Figure 9. Combined with the reduced number of hours operating, the leakage reduced from $29 \%$ for the CWS to $20 \%$ and $16 \%$ for the IWS of $15 \mathrm{~h}$ and $12 \mathrm{~h}$, respectively. These values are also slightly better than the IWS without resizing.

From an economic point of view, the implementation cost ranged from approximately 5.0 to 8.0 million reais. Considering the WDS life cycle, the resizing option was more feasible than any other solution. The efficiency of IWS of $15 \mathrm{~h}$ and $12 \mathrm{~h}$ with resizing, respectively, in relation to the CWS is: (i) scenario $1: 10.0 \%$ and $14.0 \%$; (ii) scenario $2: 36.0 \%$ and $47.4 \%$; (iii) scenario $3: 29.2 \%$ and $44.5 \%$. 

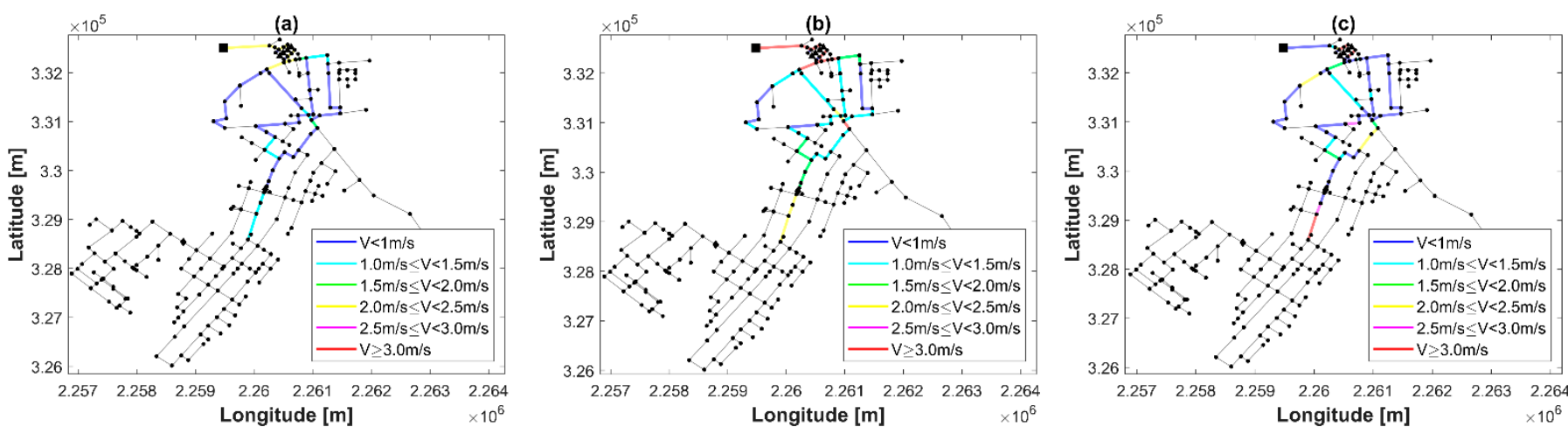

Figure 8. Velocity in the main network from the OBCL-1 network: (a) 24 h; (b) 12 h; (c) 12 h optimized.
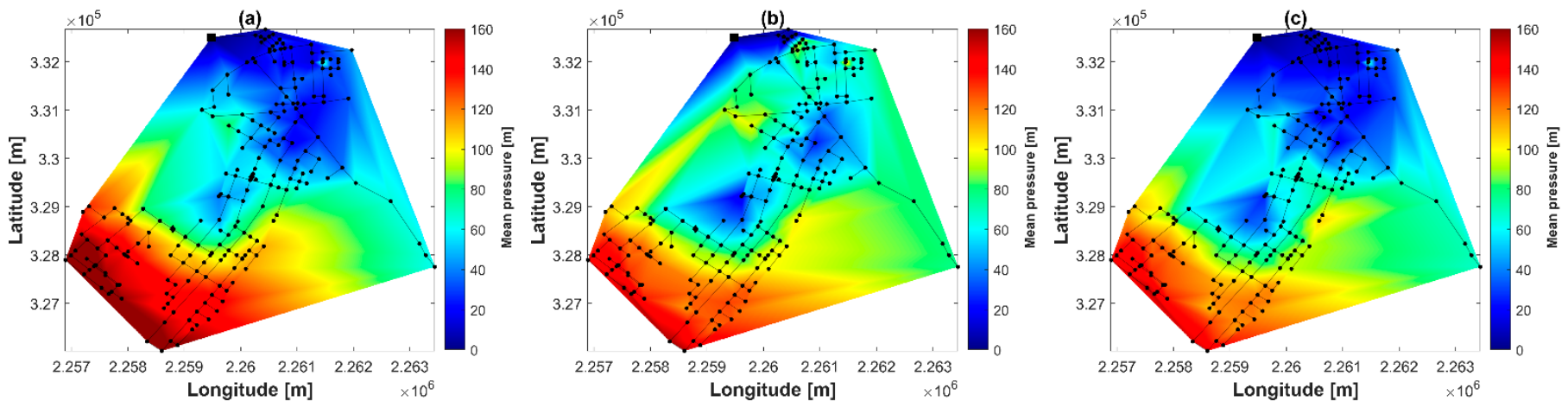

Figure 9. Mean pressure from the OBCL-1 network: (a) 24 h; (b) 12 h; (c) 12 h optimized.

\section{Conclusions}

Water-stressed conditions can impact not only the public water supply but also important sectors of the economy, such as irrigation and hydroelectric power generation. The management of water resources becomes a fundamental strategy to minimize impacts in periods of water scarcity and to reduce the conflicts associated with multiple uses of water. This paper studied the rehabilitation of main pipes as a tool to control the increase of energy consumption in IWS, as highlighted by [20]. Therefore, in locations where energy is produced mainly by hydroelectric power plants, as in Brazil, the rehabilitation is a management strategy to further reduce overload in the reservoirs during periods of water stress, to minimize conflicts from multiple uses, and to maintain the power generation capacity. In addition, the proposed methodology could be used as a planning tool for CWS, as the resizing of pipes that have the best cost-benefit ratio to improve the system capacity could meet the increasing demand with lower operational costs.

In the first case study, the ZJ network, the resizing allowed to operate the system during a reduced period of $12 \mathrm{~h}$ per day. This was not possible with the original infrastructure, as negative pressures were observed. In addition, daily leakage was just slightly better than the best-case scenario found by [20] due to an increase in mean pressure. In the second case study, the OBCL-1 network, resizing allowed to correct the increase in velocity and, consequently, decrease the head losses. Therefore, a significant reduction in both power demand and energy consumption was observed with a slightly decrease in daily leakage due to the smaller pumps, which contributed for the rehabilitation to have excellent economic efficiency results. Despite the efficiency of the optimized IWS with the resizing of the main network (optimized scenarios), the positive and negative aspects of the strategy should be highlighted. The resizing provided an optimized operating cost, reducing energy costs and leakage, in addition to providing a reduction in average pressure and controlling the increase in flow velocity. This can be a good strategy for well-managed systems, but with a high tariff of energy and water production and/or in recurrent water scarcity conditions. Moreover, a high investment is necessary, which can make the solution 
unfeasible for managers with financial difficulties/deficits. Finally, it is also necessary to plan active campaigns to assess water quality, since the pipes remain partially or totally empty for a greater number of hours daily.

Author Contributions: Conceptualization, R.G.S. and G.M.; methodology, R.G.S. and G.M.; software, R.G.S. and G.M.; validation, R.G.S. and G.M.; formal analysis, R.G.S. and G.M.; writing-original draft preparation, R.G.S., G.M., B.B. and J.I.; writing-review and editing, R.G.S., G.M., B.B. and J.I.; supervision, G.M. and B.B. All authors have read and agreed to the published version of the manuscript.

Funding: This study was financed in part by the Coordenação de Aperfeiçoamento de Pessoal de Nível Superior-Brasil (CAPES)—Finance Code 001.

Institutional Review Board Statement: Not applicable.

Informed Consent Statement: Not applicable.

Data Availability Statement: Not applicable.

Conflicts of Interest: The authors declare no conflict of interest.

\section{References}

1. Kummu, M.; Guillaume, J.H.A.; de Moel, H.; Eisner, S.; Flörke, M.; Porkka, M.; Siebert, S.; Veldkamp, T.I.E.; Ward, P.J. The world's road to water scarcity: Shortage and stress in the 20th century and pathways towards sustainability. Sci. Rep. 2016, 6, 38495. [CrossRef]

2. Moreira, M.D.S.; dos Santos, I.F.S.; Freitas, L.F.; Freitas, F.F.; Barros, R.M.; Filho, G.L.T. Energy and economic analysis for a desalination plant powered by municipal solid waste incineration and natural gas in Brazil. Environ. Dev. Sustain. 2021, 1-28. [CrossRef]

3. ANSA. Lack of Water Affected 5 Billion People by 2050. Época Magazine. Available online: https://epocanegocios.globo.com/ Mundo/noticia/2018/03/falta-de-agua-afetara-5-bilhoes-de-pessoas-ate-2050-diz-onu.html (accessed on 8 November 2021).

4. Andey, S.P.; Kelkar, P.S. Performance of water distribution systems during intermittent versus continuous water supply. J. Am. Water Work. Assoc. 2007, 99, 99-106. [CrossRef]

5. WHO; UNICEF. Progress on Drinking Water and Sanitation; WHO/UNICEF: Geneva, Switzerland, 2012.

6. Kumpel, E.; Nelson, K.L. Intermittent Water Supply: Prevalence, Practice, and Microbial Water Quality. Environ. Sci. Technol. 2016, 50, 542-553. [CrossRef]

7. WHO. Guidelines for Drinking-Water Quality; WHO Library Cataloguing-in-Publication Data: Geneva, Switzerland, 2008 ; p. 668.

8. Preciado, C.C.; Husband, S.; Boxall, J.; del Olmo, G.; Soria-Carrasco, V.; Maeng, S.K.; Douterelo, I. Intermittent Water Supply Impacts on Distribution System Biofilms and Water Quality. Water Res. 2021, 201, 117372. [CrossRef]

9. Companhia de Saneamento Básico do Estado de São Paulo-SABESP. CHESS—Crise Hídrica, Estratégia e Soluções da SABESP: Para a Região Metropolitana de São Paulo; SABESP: São Paulo, Brazil, 2015; p. 95.

10. EPA. Brazilian Energy Balance 2020 Year 2019; EPA-Empresa de Pesquisa Energética: Rio de Janeiro, Brazil, 2020 ; p. 292.

11. Ministério do Desenvolvimento Regional; Secretaria Nacional de Saneamento-SNS. Sistema Nacional de Informações Sobre Saneamento: 25 Diagnóstico dos Serviços de Água e Esgotos-2019; SNS/MDR: Brasília, Brazil, 2020; p. 183.

12. Ministério de Minas e Energia-MME; Secretaria de Planejamento e Desenvolvimento Energético-SPDE; Departamento de Desenvolvimento Energético. Plano Nacional de Eficiência Energética: Premissas e Diretrizes Básicas; SPDE/MDR: Brasília, Brazil, 2010; p. 156.

13. Palod, N.; Prasad, V.; Khare, R. Redefining the application of an evolutionary algorithm for the optimal pipe sizing problem. J. Water Clim. Chang. 2021, 12, 2299-2313. [CrossRef]

14. Bianchotti, J.D.; Denardi, M.; Castro-Gama, M.; Puccini, G.D. Sectorization for Water Distribution Systems with Multiple Sources: A Performance Indices Comparison. Water 2021, 13, 131. [CrossRef]

15. Świętochowska, M.; Bartkowska, I.; Gwoździej-Mazur, J. Energy Optimization of the Pumping Station. Environ. Sci. Proc. 2021, 9, 37. [CrossRef]

16. Capelo, M.; Brentan, B.; Monteiro, L.; Covas, D. Near-Real Time Burst Location and Sizing in Water Distribution Systems Using Artificial Neural Networks. Water 2021, 13, 1841. [CrossRef]

17. Hu, S.; Gao, J.; Zhong, D.; Deng, L.; Ou, C.; Xin, P. An Innovative Hourly Water Demand Forecasting Preprocessing Framework with Local Outlier Correction and Adaptive Decomposition Techniques. Water 2021, 13, 582. [CrossRef]

18. Sambito, M.; Piazza, S.; Freni, G. Stochastic Approach for Optimal Positioning of Pumps as Turbines (PATs). Sustainability 2021, 13, 12318. [CrossRef]

19. Creaco, E.; Galuppini, G.; Campisano, A.; Ciaponi, C.; Pezzinga, G. A Bi-Objective Approach for Optimizing the Installation of PATs in Systems of Transmission Mains. Water 2020, 12, 330. [CrossRef]

20. Souza, R.G.M. Avaliação Hidroenergética de Sistemas de Distribuição de Água: Suprimento Contínuo versus Intermitente. Master's Thesis, Federal University of Minas Gerais-UFMG, Belo Horizonte, Brazil, November 2021. 
21. Rossman, L.A. EPANET User's Manual; US Environmental Protection Agency (EPA): Cincinnati, OH, USA, $1994 ;$ p. 200.

22. Gomes, H.P. Abastecimento de Água; LENHS/UFPB: João Pessoa, Brazil, 2019; p. 464.

23. Móller, D.S.; Lima, G.M.; Brentan, B.M.; Barros, D.B. Optimal pump selection for variable speed operation in water distribution network. RBRH 2020, 25. [CrossRef]

24. Brazil. Instituto Nacional de Metrologia, Normalização e Qualidade Industrial-INMETRO. Portaria $n^{\circ} 455$, de 01 de Dezembro 2010. Requisitos de Avaliação da Conformidade para Bombas e Motobombas Centrífugas. Diário Oficial União Brasília. Available online: http:/ /www2.aladi.org/nsfaladi/normasTecnicas.nsf/09267198f1324b64032574960062343c/e380ed588b45568f03257 9e4004f416e/\$FILE/Portaria\%20N\%C2\%B0\%20455-2010.pdf (accessed on 1 January 2012).

25. Van Zyl, J.E.; Lambert, A.O.; Collins, R. Realistic Modeling of Leakage and Intrusion Flows through Leak Openings in Pipes. J. Hydraul. Eng. 2017, 143, 04017030. [CrossRef]

26. Schwaller, J.; Van Zyl, J.E.; Kabaasha, A.M. Characterising the pressure-leakage response of pipe networks using the FAVAD equation. Water Supply 2015, 15, 1373-1382. [CrossRef]

27. Van Zyl, J.E.; Malde, R. Evaluating the pressure-leakage behaviour of leaks in water pipes. J. Water Supply Res. Technol. 2017, 66, 287-299. [CrossRef]

28. Associação Brasileira de Normas Técnicas-ABNT. NBR 12215-1: Projeto de Adutora de Água Parte 1: Conduto Forçado; ABNT: Rio de Janeiro, Brazil, 2017; p. 26.

29. Campbell, E.; Izquierdo, J.; Montalvo, I.; Ilaya-Ayza, A.E.; Pérez-García, R.; Tavera, M. A flexible methodology to sectorize water supply networks based on social network theory concepts and multi-objective optimization. J. Hydroinform. 2016, 18, 62-76 [CrossRef]

30. Maiolo, M.; Pantusa, D.; Carini, M.; Capano, G.; Chiaravalloti, F.; Procopio, A. A New Vulnerability Measure for Water Distribution Network. Water 2018, 10, 1005. [CrossRef]

31. Meijer, D.; Post, J.; Van der Hoek, J.P.; Korving, H.; Langeveld, J.; Clemens, F. Identifying critical elements in drinking water distribution networks using graph theory. Struct. Infrastruct. Eng. 2021, 17, 347-360. [CrossRef]

32. El-Ghandour, H.A.; Elabd, S.M.; Elbeltagi, E. Assessment of optimal water distribution systems design under steady-state and transient conditions due to pipe roughness uncertainty. Ain Shams Eng. J. 2021, 12, 465-473. [CrossRef]

33. Di Nardo, A.; Giudicianni, C.; Greco, R.; Herrera, M.; Santonastaso, G.F. Applications of Graph Spectral Techniques to Water Distribution Network Management. Water 2018, 10, 45. [CrossRef]

34. Hajebi, S.; Roshani, E.; Cardozo, N.; Barrett, S.; Clarke, A.; Clarke, S. Water distribution network sectorisation using graph theory and many-objective optimisation. J. Hydroinform. 2015, 18, 77-95. [CrossRef]

35. Companhia Energética de Minas Gerais-CEMIG. Valores de Tarifas e Serviços; CEMIG: Belo Horizonte, Brazil, 2020; Available online: https:/ / www.cemig.com.br/atendimento/valores-de-tarifas-e-servicos/ (accessed on 13 December 2020).

36. Gomes, H.P. Avaliação Econômica: Eficiência Energética, 1st ed.; Editora UFPB: João Pessoa, Brazil, 2014; p. 100. ISBN 978-85-237-0818-4.

37. Sistema Nacional de Pesquisa de Custos e Índices da Construção Civil—SINAPI. Preço de Insumos e Composições. Mês de Referência: Março de 2021. Belo Horizonte. 2021. Available online: https:/ /www.caixa.gov.br/site/Paginas/downloads.aspx\# categoria_648 (accessed on 30 April 2021).

38. Secretaria da Infraestrutura do Estado do Ceará-SEINFRA. Tabela de custos. Mês de Referência: Março de 2021. Fortaleza. 2021. Available online: https:/ / www.seinfra.ce.gov.br/tabela-de-custos/ (accessed on 30 April 2021).

39. Companhia Paulista de Obras e Serviços_CPOS. Tabela de Custos. Mês de Referência: Março de 2021. São Paulo. 2021. Available online: https:/ / www.prefeitura.sp.gov.br/cidade/secretarias/obras/tabelas_de_custos/index.php?p=310197 (accessed on 30 April 2021).

40. Kennedy, J.; Eberhart, R. Particle swarm optimization. In Proceedings of the ICNN'95-International Conference on Neural Networks, Perth, WA, USA, 27 November-1 December 1995; Volume 4, pp. 1942-1948.

41. Goldbarg, E.; Goldbarg, M.; Luna, H. Otimização Combinatória e Metaheurísticas: Algoritmos e Apliacações; Elsevier: Rio de Janeiro, Brasil, 2017.

42. Hernandez, E.; Hoagland, S.; Ormsbee, L.E. WDSRD: A Database for Research Applications. 2016. Available online: http: //www.uky.edu/WDST/database.html (accessed on 28 December 2020). 